\title{
$\underline{\text { Language Policy and Education in Canada }}$
}

Volume 1: Language Policy and Political Issues in Education

Barbara Burnaby

Memorial University of Newfoundland 
Introduction

This sketch of Canadian language legislation and policies touches on background information, French and English as official languages, official and minority language policies for immigrants, and policies on Aboriginal languages.

Canada, a large country with a relatively small population (30 million), has a parliamentary democracy. Created legally in 1867, it now has ten provinces and three territories. Constitutionally, the federal government has jurisdiction over Aboriginal matters and the territories, the provinces over education; responsibility for immigration is shared.

In about 1500, Aboriginal people lived across what is now Canada, speaking about 450 languages and dialects from 11 language families. Immigration, starting with colonization by Britain and France, has since increased the population and changed its ethnic/racial mixture. Although immigration from northern and western Europe predominated earlier, the proportion of immigrants from other continents has increased, particularly since the 1960s. In 2001, 59\% of the population reported English as mother tongue, 23\% French, less than 1\% Aboriginal languages, and 17\% other languages (Statistics Canada, 97F0007XCB2001001). 
French and English as Official Languages

Struggles first between France and Britain, then Francophones and Anglophones dominate Canada’s recorded history. In the 19th century, Canadian legal rights for the 'English' and 'French' populations focussed on religion rather than language (Neatby in Commissioner of Official Languages, 1992, pp.v-ix). Legislation specifically on language was rare. However, in the early 20th century, increased secularism, industrialization, national attention on Canada’s role in the British Empire, and massive immigration encouraged a movement to 'Angloconformity', especially through legislated use of English as the language in schools in most provinces. Francophones in Quebec were isolated in a French-language, church-run school system and in the social and political use of French in some areas of Quebec. Only superficially did the federal government recognize the constitutionally equal status of French with English in Parliament, in federal courts, and in the legislature and courts of Quebec.

After 1945, industrialization, immigration, and a low birth-rate among Francophones threatened the critical mass of French even in Quebec (Neatby in Commissioner of Official Languages, 1992, p.vii). Most non-French immigrants to Quebec chose English as their second language, English being the dominant language of large business in Quebec, centred in Montreal. Being ethnically Quebecois and unilingually Francophone was a severe economic disadvantage up to the early 1960s (Wardhaugh, 1983, pp.74-80). In the 1960s, Francophones in Quebec, through the "Quiet Revolution” movement, acted to gain more control. In 1963, the Quebec government created a ministry of education, replacing the parochial education system. 
Such pressures moved the federal government to take the constitutionally equal status of the French language seriously. It established the Royal Commission on Bilingualism and Biculturalism (1963-1971) which made an elaborate study of political, cultural, and economic use of all languages in Canada except the Aboriginal languages. The impact of its research began in 1964 with language training for public servants, leading, in 1973, to measures to make English and French equitably the languages of work in the federal civil service (Commissioner of Official Languages, 1992, pp.14-17; Beaty, 1989, p.186).

From 1967 on, some provinces, anticipating the commission's impact, changed their education acts towards more use of French as language of instruction (Commissioner of Official Languages, 1992, pp.14-15). In a Montreal suburb, a group of Anglophone parents in 1965 persuaded a school board to teach their children through the medium of French so that the children would learn it as a second language faster and more effectively (Lambert \& Tucker, 1972). This launched the now popular 'French immersion' programs across the country. In virtually every part of the country, various versions of these programs are now a significant part of Canadian public education (Swain, this encyclopedia, Volume V; Lapkin, 1998).

The main outcome of the Royal Commission's Report was the Official Languages Act of 1969, making English and French Canada’s official languages. 
In addition to declaring that English and French are to have 'equality of status and equal rights and privileges' for all the purposes of the Parliament and Government of Canada, the Act specifically imposes duties on all federal institutions to provide their services in either English or French: in the National Capital Region and in such 'bilingual districts' as might be subsequently designated, at their head offices, and in any other locations where there was 'significant demand' for such services. The Act also created the position of Commissioner of Official Languages to oversee its implementation and generally act as official languages ombudsman. (Beaty, 1989, pp.185-186)

Beaty summarizes the main programs supporting the Official Languages Act as encouraging 'a more general climate of respect and support for Canada's official languages in other jurisdictions and in Canadian society as a whole’:

- by supporting minority groups [English in Quebec and French elsewhere] in their attempts to achieve provincial recognition of their legal rights and their special linguistic needs;

- by fostering and helping to finance minority language education...;

- by giving similar financial encouragement to the effective learning of English and French as a second language country-wide; and - by supporting the efforts of national, private and voluntary organizations to 
develop their own capacity to do business in both official languages. (Beaty, 1989, p.190-191)

In 1970-1971, the federal government began its Official Languages in Education (OLE) Program. Education being a provincial responsibility, the federal government could not legislate on it directly but could encourage compliance by offering funding. Following the Royal Commission's recommendation that the federal government support the provinces in providing English education for Anglophones in Quebec and French education for Francophones in the other provinces, and in improving second official language instruction, the OLE has made transfer payments to provinces, monitored by the Commissioner of Official Languages. Although the enrolment in English schooling in Quebec and French schooling elsewhere has not changed substantially since 1971, numbers of children in second official language programs have, especially French immersion programs (Canadian Education Association, 1992, p.3; Canadian Parents for French, 2004).

The province of New Brunswick declared itself bilingual in 1969, and most provinces legislated more status for French in the next few years. A series of actions in Quebec, especially relating to parents’ rights to have their children educated in languages other than French, provoked controversy. Separatism became a driving force in the province, but the Quebec government in 1980 (and in 1995) lost a referendum for a mandate to negotiate 'sovereignty association’ (Quebec nationalism within the Canadian state) with the federal government 
(Commissioner of Official Languages, 1992, pp.9-22; Labrie, 1992, pp.30-32). In this climate, the nation made a number of efforts in the 1970s to prevent a total rift with Quebec.

In 1980, the federal government 'patriated' the constitution, providing a major opportunity for constitutional changes. Canada's constitution was an act of the British Parliament; patriation meant enacting some form of it through the Canadian Parliament. The 1982 Constitution Act left the major structure, such as the responsibilities of the federal and provincial governments, the same. It added an amending formula, as well as the Canadian Charter of Rights and Freedoms, which included central developments on language since the early 1960s, such as the official language status of English and French for the governments of Canada and New Brunswick. Citizens can now challenge all legislation and policies in court against the Charter provisions.

Crucially, Quebec did not agree to the Constitution Act because of concerns about its amending formula. Despite attempts at resolution, 2005 finds federal relationships uneasy, with the inclusion of Quebec in the constitution unresolved. As for language in education, the Act precipitated many legal actions to align mother-tongue education provisions for Francophone children in English Canada and Anglophone children in Quebec with the Charter (Foucher, 1985; Martel, 1991). The Commissioner of Official Languages noted recently that only half the students from Francophone minority communities who are entitled to attend Francophone schools do so (Commissioner of Official Languages, 2003, p.10). Official second language 
programs for Anglophones and Francophones have been relatively uncontroversial.

The evolution of English and French as official languages and languages of education, work, commerce, and so forth during the past forty years provides no perfect model for language relations, especially since it has not yet satisfied either party. However, it has set a certain standard for some other language minorities in the country. The intense negotiations between Quebec and the rest of Canada still dominate discussion at the national and provincial levels.

Language Issues for Speakers of Non-Official Languages

Reading official statements, one would scarcely believe that Canadians speak languages other than English and French. Federal statements carefully refer to speakers of non-official languages as other cultural groups. However, given the important role of immigration in Canada, to say nothing of the special position of the Aboriginal peoples, non-official languages are very much in evidence. This section discusses language issues for speakers of non-official languages other than Aboriginal ones. It refers to 'immigrants' even though non-official language issues often continue well into the second and third generations after immigration.

Official Language Training for Those Who Speak Neither Official Language 
Federal legislation covers official languages for those who speak an official language already; no federal legislation even suggests that speakers of neither English nor French have the right to support in learning one of those languages. However, some programs address language for residents of Canada who do not speak either official language. Federal policy on official languages in education for Anglophones or Francophones refers almost entirely to children's education, but official language training for non-official language groups mainly targets adults, largely because the federal government strongly links immigration to the labourforce.

The Official Languages Act (1969) makes no provisions for the learning of official languages by residents of Canada who do not speak either language (well). However, in 1971, the federal government declared itself by policy multicultural. Clearly aimed at calming backlash among non-English/French groups over the declaration of official languages, the multiculturalism policy pledged to promote respect and support for all of Canada's languages and cultures. The original policy stated that 'the government will continue to assist immigrants to acquire at least one of Canada's official languages in order to become full participants in Canadian society' (Saouab, 1993, p.4). The policy passed through various stages, none including direct support for official language training for immigrants, and evolved into the present Multiculturalism Act (1988), which mainly fosters non-English and French cultures, anti-racism, and affirmative action in support of visible minorities.

Since about 1970, the Immigration Act has increasingly made knowing one official language an advantage in admissibility for certain classes of immigrants, but only some 
applicants are assessed this way. To become a Canadian citizen applicants must demonstrate a 'reasonable' knowledge (undefined) of either official language. From the early 1970s to the late 1980s, the federal department responsible for the Citizenship Act made agreements with most provinces for partial funding of provincial language and citizenship training for adults.

However, the federal government emphasized more the economic impact of immigration. The federal agency responsible for employment included language training for immigrants 'bound for the labourforce' under its large program of employment (re)training from the late 1960s to about 1990. The provinces' community colleges did the training (to accommodate education as a provincial responsibility) but federal officials chose the students. This program provided about 24 weeks of full-time training with a training allowance. Controversy surrounded this program, especially concerning decisions on who was destined for the labourforce. Meanwhile, since the 1960s, provinces, local authorities, and non-governmental organizations (NGOs) have provided a wide variety of language training to immigrants.

Since 1991, the employment-related federal program has been replaced by one serving immigrants who do not yet have Canadian citizenship, regardless of their labour market intentions. This includes individual assessment against nation-wide language standards, counselling, and recommendations on local programs. Canadian Language Benchmarks and Standards linguistiques canadiens, assessments of English and French language ability including task-based level descriptors, provide the standards for assessment and curriculum (Centre for 
Canadian Language Benchmarks, 2005). Private and public institutions bid annually for contracts to provide training, either generic or targeted (e.g., for immigrants with low levels of education). Childminding and transportation may be provided, but no training allowances. Criticisms of this program include that: newcomers who have obtained Canadian citizenship are not eligible; federal authorities have left provinces and NGOs with the main language training burden; and the one-year contract bids stress the bidding agencies (Burnaby 1992, 1996).

ESL for schoolchildren is simpler than adult programs only in being delivered almost exclusively by school boards. In areas where there is little immigration (e.g. the Atlantic provinces), immigrant children may be unevenly served if at all; however, in high-immigration regions, they usually get at least minimal attention, such as special classes, withdrawal from regular classes for part of the day, or sensitization of regular teachers to their needs (Ashworth, 1992, pp.36-40). There are no bilingual programs to help orient children to Canadian schooling. Some part-time classes for immigrant women have been funded as 'parents and preschoolers' programs so that the children get some language training too. A series of articles in The Globe and Mail (September, 2004) by Andrew Duffy indicated increasing stress points for non-English speaking students in English Canadian schools as well as some extraordinary programs to address their needs (Duffy, 2004).

Teaching of Non-Official Languages as Ancestral Languages 
Clearly Canada greatly values its official languages. But what of the value of other languages that immigrants bring to Canada? In the era of greatest Anglophone power, the system viewed languages other than English with suspicion, and encouraged immigrants, especially children, to forget their mother tongues. From the 19th century, some immigrant communities organized and funded non-official language classes for their children. Until the early 20th century, when provincial education acts were changed to prevent them, there were some publically-supported bilingual schools. Some religious groups struggled long into this century against compulsory English schooling (Ashworth, 1992, p.40). Some immigrant groups have continued to fund private multilingual schools or classes in non-official languages.

The Official Languages Act of 1969 provoked a climate of linguistic uncertainty for nonofficial languages; the 1971 policy of multiculturalism hinted at some recognition of them. In 1977, under that policy, the federal government created the Cultural Enrichment Program. It included support for the teaching of non-official languages, primarily to children of communities where the target language was a 'heritage language' (the mother tongue or ancestral language of the children). Extensive and vitriolic resistance to the establishment of heritage language classes at public expense developed (Cummins \& Danesi, 1990, ch.3; d'Anglejan \& de Koninck, 1992, pp.100-101; Fleras \& Elliott, 1992, pp.155-159). Since 1977, some programs have been associated with the schools and at least partially publically funded, and new ones have been created in the schools, but most remain non-academically-recognized add-ons (Ashworth, 1992; Canadian Education Association, 1991; d’Anglejan \& de Koninck, 1992; Toohey, 1992). 
Although the multiculturalism policy and Act encouraged learning of official languages, heritage language programs were never associated with fiscal support for official language training programs (i.e., linked to issues of children at risk concerning the learning of English or French).

Language Policies for Aboriginal Peoples

Official policy has largely considered Aboriginal peoples and their languages as outside the debates outlined above. Since Confederation in 1867, Aboriginal people-'Indians' in the British North America Act of 1867 and 'Eskimos' by a court ruling in 1939--were constitutionally the federal government's responsibility for all services. The Royal Commission on Bilingualism and Biculturalism excluded them on the grounds that their issues were more properly dealt with elsewhere. They have not been included, largely by their own choice, in subsequent definitions of cultural minorities. Administrations kept them isolated from the rest of the population. Such separate treatment left open opportunities for special policies suited to their unique needs; unfortunately, most of these opportunities have been wasted in racist and assimilative ways (National Indian Brotherhood, 1972; Royal Commission on Aboriginal Peoples, 1996).

Comparison of the proportions of mother tongue speakers of Aboriginal languages among the Aboriginal population from the censuses of 1951 to 2001 dramatically illustrates a 
decline of Aboriginal languages. In 1951, 87.4\% of the Aboriginal population had an Aboriginal language as a mother tongue whereas in 1981 it was 29.3\% (Burnaby \& Beaujot, 1986, p.36) and in 2001, it was 21\% (Statistics Canada, 97F0011XCB2001048). Clearly, Aboriginal languages in Canada are at great risk (some much more than others).

Although Aboriginal languages were sometimes used in Aboriginal education in the 19th and early 20th centuries, more often draconian Aboriginal education policies forced Aboriginal children to speak English or French in school, even to the extent of severe physical punishment for speaking an Aboriginal language. Until about the 1950s, schooling for Aboriginal children was mostly contracted to Christian groups; a later policy moved to integrate all Aboriginal children into provincial schools or, in remote areas, to establish federally-run schools. Today, those federal schools are largely run by local Aboriginal authorities. Since the 1960s, Aboriginal languages have increasingly been taught in Aboriginal and provincial schools as subjects of instruction (Assembly of First Nations, 1990; Kirkness \& Bowman, 1992). In addition, Aboriginal languages have been introduced recently as medium of instruction up to the third grade in some schools in the territories and Quebec, where the children begin school speaking only or mainly their Aboriginal language. Aboriginal language immersion programs have begun in several southern communities, where the children start school speaking only or mainly an official language. Nine Aboriginal languages have been made official languages in the Northwest Territories together with English and French, and the new (1999) territory of Nunavut, having declared Inuktitut, Inuinaqtun, French and English as its official languages, is 
actively developing policies for extensive use of these languages in many domains (Government of Nunavut, 2005).

Despite improvements in Aboriginal language programming in schools, Churchill’s (1986) findings that policies for indigenous groups cluster at the lower levels of his scale of policy development--in that most programs are for the youngest children, only for a few years, inadequately funded, and seen to be transitional to fluency in an official language--still stands. Although there are many more programs in the early $21^{\text {st }}$ Century, current survey data (Burnaby, 2002) give the same impression Clarke and MacKenzie (1980) got in their study of Aboriginal language programs--namely, that Aboriginal language programs give only lip service to pluralism and are actually assimilationist in intent. A significant development is the creation of an extensive Aboriginal language and culture curriculum, adopted by Manitoba, Saskatchewan, Alberta, British Columbia, and the three territories (Western Canadian Protocol, 2000). Conclusions

Canada’s largest minority, Francophones, have challenged Canadian Anglo-dominance to the point of constitutional crisis. Smaller linguistic groups unfavourably compare the resources supporting official language services for English and French speakers with those available to them even to learn a first official language, much less enhance their own languages. Aboriginal groups, many of whose languages face extinction, struggle particularly about priorities between language efforts and political and economic recognition. A needs assessment of language 
resources in the new global order might recommend a reorganization of Canada's language

emphases. Much sophisticated thinking in Canada about language policy (e.g., Fettes, 2003;

Kymlicka \& Patten, 2003) does not seem to be taken very seriously in Canadian language policy

development overall, except in the territories. 
References

Ashworth, M.: 1992, 'Views and Visions’ in B. Burnaby \& A. Cumming (eds.), Socio-political Aspects of ESL in Canada, OISE Press, Toronto, 35-49.

Assembly of First Nations: 1990, Towards Linguistic Justice for First Nations, Education Secretariat, Assembly of First Nations, Ottawa.

Beaty, S.: 1989, ‘A New Official Languages Act for Canada--Its Scope and Implications’, in P. Pupier \& J. Woehrling (eds.), Language and Law: Proceedings of the First Conference of the International Institute of Comparative Linguistic Law, Wilson and Lafleur, Montreal, 185-193.

Burnaby, B. \& Beaujot, R.: 1986, The Use of Aboriginal Languages in Canada: An Analysis of 1981 Census Data, Social Trends Analysis Directorate and Native Citizens Directorate, Department of the Secretary of State, Ottawa.

Burnaby, B.: 1992, 'Official Language Training for Adult Immigrants in Canada: Features and Issues’, in B. Burnaby \& A. Cumming (eds.), Socio-political Aspects of ESL in Canada, OISE Press, Toronto, 3-34.

Burnaby, B.: 1996, 'Language Policies in Canada: An Overview’, in M. Herriman \& B. Burnaby (eds.), Language Policy in English-Dominant Countries: Six Case Studies, Multilingual Matters, Clevedon, England.

Burnaby, B.: 2002, Provincial Governments’ Initiatives in Aboriginal Language and Cultural Education, Department of Indian and Northern Affairs, Ottawa.

Canadian Education Association: 1991, Heritage Language Programs in Canadian School 
Boards, Canadian Education Association, Toronto.

Canadian Education Association: 1992, French Immersion Today (CEA Information Note), Canadian Education Association, Toronto.

Canadian Parents for French: 2004, The State of French Second Language Education in Canada, 2004, Canadian Parents for French, Ottawa.

Centre for Canadian Language Benchmarks: (retrieved from www.language.ca February 17, 2005), Centre for Canadian Language Benchmarks, Ottawa.

Churchill, S.: 1986, The Education of Linguistic and Cultural Minorities in the OECD Countries, Multilingual Matters, Clevedon, England.

Clarke, S. \& MacKenzie, M.: 1980, 'Education in the Mother Tongue: Tokenism versus Cultural Autonomy in Canadian Indian Schools’ Canadian Journal of Anthropology 1 (2), 205-217.

Commissioner of Official Languages: 1992, Our Two Official Languages Over Time (revised edition), Office of the Commissioner of Official Languages, Ottawa.

Commissioner of Official Languages: 2003, Office of the Commissioner of Official Languages Performance Report for the Period Ending March 31, 2003, Office of the Commissioner of Official Languages, Ottawa.

Cummins, J. \& Danesi, M.: 1990, Heritage Languages: The Development and Denial of Canada's Linguistic Resources, Our Schools/Our Selves Education Foundation and Garamond Press, Toronto.

d'Anglejan, A. \& De Koninck, Z.: 1992, ‘Educational Policy for a Culturally Plural Quebec: An Update', in B. Burnaby \& A. Cumming (eds.), Socio-political Aspects of ESL in Canada, OISE 
Press, Toronto, 97-109.

Duffy, A.: 2004, 'Class Struggles: Public Education and the New Canadian' www.atkinsonfoundation.ca/files/Duffy_web.pdf.

Fettes, M.: ‘Critical Realism, Ecological Psychology, and Imagined Communities’, in J. Leather \& J. van Dam (eds.), Ecology of Language Acquisition, Kluwer, Dordrecht, 31-47.

Fleras, A. \& Elliott, J.L.: 1992, The Challenge of Diversity: Multiculturalism in Canada, Nelson Canada, Scarborough, Ontario.

Foucher, P.: 1985, Constitutional Language Rights of Official-Language Minorities in Canada: A Study of the Legislation of the Provinces and Territories Respecting Education Rights of Official-Language Minorities and Compliance with Section 23 of the Canadian Charter of Rights and Freedoms, Supply and Services Canada, Ottawa.

Government of Nunavut: (retrieved from www.gov.nu.ca/Nunavut/English/departments/CLEY, February 20, 2005), Department of Culture, Language, Elders and Youth, Government of Nunavut, Iqaluit.

Kirkness, V. \& Bowman, S.: 1992, First Nations and Schools: Triumphs and Struggles, Canadian Education Association/ Association canadienne d'éducation, Toronto.

Kymlicka, W. \& Patten, A.(eds.): 2003, Language Rights and Political Theory, Oxford, New York, Oxford University Press.

Labrie, N.: 1992, 'The Role of Pressure Groups in the Change of the Status of French in Québec since 1960', in U. Ammon \& M. Hellinger (eds.), Status Change of Languages, De Gruyter Verlag, Berlin and New York, 17-43. 
Lambert, W.E. \& Tucker, G.R.: 1972, Bilingual Education of Children: The St. Lambert Experiment, Newbury House, Rowley, Massachusetts.

Lapkin, S. (ed.): 1998, French Second Language Education in Canada: Empirical Studies, University of Toronto Press, Toronto and Buffalo.

Martel, A.: 1991, Official Language Minority Education Rights in Canada: From Instruction to Management, Office of the Commissioner of Official Languages, Ottawa.

National Indian Brotherhood: 1972, Indian Control of Indian Education, National Indian Brotherhood, Ottawa.

Royal Commission on Aboriginal Peoples: 1996, Report of the Royal Commission on Aboriginal Peoples (www.ainc-inac.gc.ca/ch/rcap/sg/sgmm_e.html), Indian and Northern Affairs Canada, Ottawa.

Royal Commission on Bilingualism and Biculturalism: 1967, Report of the Royal Commission on Bilingualism and Biculturalism: General Introduction and Book I, The Official Languages, The Queen's Printer, Ottawa.

Saouab, A.: 1993, Canadian Multiculturalism, Library of Parliament, Research Branch, Supply and Services Canada, Ottawa.

Statistics Canada: (retrieved from www12.statcan.ca February 16, 2005), Language Composition of Canada (catalogue number 97F0007XCB2001001), Statistics Canada, Ottawa.

Statistics Canada: (retrieved from www12.statcan.ca February 20, 2005), Selected Demographic and Cultural Characteristics (199), Aboriginal Origin (14), Age Groups (6), Sex (3) and Area of Residence, for Population, for Canada, Provinces and Territories, 2001 Census - 20\% Sample 
(catalogue number 97F0011XCB2001048), Statistics Canada, Ottawa.

Toohey, K.: 1992, 'We Teach English as a Second Language to Bilingual Students’, in B. Burnaby \& A. Cumming (eds.), Socio-political Aspects of ESL in Canada, OISE Press, Toronto, 87-96. Wardhaugh, R.: 1983, Language and Nationhood: The Canadian Experience, New Star Books, Vancouver.

Western Canadian Protocol for Collaboration in Basic Education, 2000, The Common Curriculum Framework for Aboriginal Language and culture Programs, Kindergarten to Grade 12, (retrieved from www.wcp.ca, February 20, 2005). 